\title{
EXTERNAL DEBT IMPLICATIONS \\ ON THE DEVELOPMENT OF NATIONAL ECONOMY
}

\author{
Victoria IORDACHI', PhD in Economics, Associated Researcher, \\ National Institute for Economic Research, Republic of Moldova \\ Stela CIOBU ${ }^{2}$, PhD in Economics, Associated Professor, \\ Academy of Economic Studies of Moldova
}

\author{
DOI: https://doi.org/10.36004/nier.es.2019.2-03 \\ JEL Classification: E42, E52, E58 \\ UDC: $336.273 .3(478)$
}

\section{ABSTRACT}

The external debt of the Republic of Moldova is increasing constantly. Excessive external debt has been a big problem for both developing and developed countries during the years. Developing countries face this problem more often as they need to borrow to finance their objectives and strengthen the economic growth. It is very important for our country to determine the optimal level of indebtedness that the economy can bear. That is why the external debt should be contracted in strict accordance with the needs of the economy, and borrowed loans should consider the country's reimbursement capacities to avoid the liquidity or solvency crisis. The scope of this paper is to give a prompt and correct overview of the importance of external debt management and its impact on the economic growth of the country. In the research process, the deduction, based on general theoretical information on the structure, management, external debt and indebtedness assessment, the economic influence policies were used and then passed on to practical analysis using specific indicators.

Keywords: gross external debt, Gross Domestic Product, price stability, inflation pressures, foreign currency, economic crisis.

Datoria externă a Republicii Moldova este în continuă creștere. Datoria externă excesivă a fost o mare problemă atât pentru țările în curs de dezvoltare, cât și pentru cele dezvoltate de-a lungul anilor. Țările în curs de dezvoltare se confruntă mai des cu această problemă, întrucât trebuie să împrumute pentru a-și finanța obiectivele și pentru a consolida creșterea economică. Este foarte important pentru țara noastră să determine nivelul optim de îndatorare pe care economia îl poate suporta. Acesta este motivul pentru care datoria externă ar trebui contractată în concordanță strictă cu nevoile economiei și luând în considerare capacitătile de rambursare, pentru a evita criza de lichiditate sau de solvabilitate. Scopul acestei lucrări este de a oferi o imagine generală promptă și corectă a importanței gestionării datoriei externe și a impactului acesteia asupra creșterii economice a țării. In procesul de cercetare a fost utilizată deducerea bazată pe informații teoretice generale privind structura și managementul datoriei externe, precum și evaluarea îndatorării, politicile de influență economică și apoi analiza practică, folosind indicatori specifici.

Cuvinte-cheie: datora externă brută, Produsul Intern Brut, stabilitatea prețurilor, presiuni inflaționiste, valută străină, criză economică.

Внешний долг Республики Молдова постоянно увеличивается. В течение многих лет чрезмерная внешняя задолженность была большой проблемой как для развивающихся, так и для развитых стран. Развивающиеся страны сталкиваются с этой проблемой чаще, поскольку им необходимо брать кредиты для финансирования своих целей и усиления экономического роста. Для нашей страны очень важно определить оптимальный уровень задолженности, который может выдержать экономика. Вот почему внешний долг следует заключать в строгом соответствии с потребностями экономики, а заемные кредиты должны учитывать возможности их возмещения, чтобы избежать кризиса ликвидности или платежеспособности. Цель этой статьи - дать

1 C Victoria IORDACHI, $₫$ timush_v@yahoo.co.uk

2 (C) Stela CIOBU, stela.ciobu@gmail.com

No. 2 / 2019 
быстрый и правильный обзор значимости управления внешним долгом и его влияния на экономический рост страны. В процессе исследования использовалась дедукция, основанная на общей теоретической информации о структуре, управлении, оценке внешнего долга и задолженности, политике экономического влияния, а затем переход к практическому анализу с использованием конкретных показателей.

Ключевые слова: валовой внешний долг, валовой внутренний продукт, ценовая стабильность, инфляционное давление, иностранная валюта, экономический кризис.

INTRODUCTION. Excessive external debt has been a big problem for both developing and developed countries during the years. Developing countries face this problem more often as they need to borrow to finance their objectives and strengthen the economic growth. However, these borrowings have to be strictly managed and must be allocated properly for productive expenditures in accordance to their repayment ability. Though the debt is useful to supplement the capital, it must be managed and controlled very carefully, proper strategies have to be adopted for enforcing repayment ability of the country. High level of external debt has a negative impact on the economy in terms of heavy debt servicing and decreased development expenditures, essential in carrying the growth process. However, less funds for investing in the economy and an increase in tax regime for repayment, disturbs the economic growth as it constraints the productive investment, leading to a narrow debt repayment ability of the country. It has a negative impact on the foreign and national investment, and development objectives of the country.

The economic growth is one of the aspirations of all economies, as it leads to a rise in per capita income, to raising the standards of living of the population, to the overall development of the national economy, and, finally, to the economic progress.

A developing country in the transition from the centralized to the market economy cannot build a solid democracy, based on a competitive economy and a modernized economic and social infrastructure system, rather than by calling for funding external debt generating unit. Considered to be at the heart of the development of the capitalist economies, the credit is widely used at macroeconomic level. Both developed and developing countries resort to domestic or foreign credits because they offer them the opportunity to spend now and pay in a future period when the investment starts to make a profit.

I. The impact of the external debt on the national economy

External debt as a policy to promote economic growth creates serious debates between economists and the policy makers. The main issue is whether or not external borrowing leads to economic growth in debtor countries or affect it negatively. This issue results in two main perspectives for explaining the relationship between external debt and economic growth.

On the one hand, the neoclassical growth models support that there is a positive relationship between external debt and economic growth. They consider that external debt is one source for financing capital formation, and if financing capital formation through borrowing, it could promote the economic growth.

On the other hand, Krugman contradicts this view and tells that the external debt is one of the barriers that prevent the economic growth. Kalonji explained that excessive external debt is a cause of poverty in the debtors' countries [4, KRUGMAN, P., 1988].

This ideology shows us that a country should borrow from abroad as long as the capital is not sufficient and it will produce a rate of return that is higher than the cost of the borrowing. In this way, developing countries with an inadequate capital will keep borrowing to fill the national savings and investment. They will borrow at a rate that depends on the relation among foreign and national savings, investment and economic growth so in that way, the borrowing countries will increase their output with the help of foreign savings. This procedure will be effective only if the borrowing will be managed efficiently and the rate of return will be higher than the cost of borrowing.

Economic theories suggest that reasonable levels of external debt lead to an economic growth. Countries at early stages of development have small levels of capital and stocks and need the investments with less interest rate lower than in developed countries. As they use the borrowed funds adequately for productive purposes and do not suffer from macroeconomic instability, policies that twist the economic incentives, these funds will help the economy and lead to an economic growth and will allow for timely debt repayments [10, PATILLO, C., RICCI, L., 2002]. These theories are also proved in more realistic predictions that countries may not be able to borrow freely because of the risk of debt repudiation. 
The most common question for economist and policy makers is: Why do excessive debt leads to a lower economic growth? Well, the best known answer to this question comes from "debt overhang" theories, which show us that most likely, the debt will be higher than the country's repayment ability, and expected debt service costs will discourage further domestic and foreign investments, and will harm the economic growth. Potential investors will fear to invest as they will consider that if a country produces more, it will be taxed by creditors to service the external debt, and thus they will be willing less to incur costs today for the sake of increased output in the future. This argument claims that large debt stocks lead to a lower probability of debt repayment.

Although the debt overhang models don't show the effects on growth in particular, but it shows quiet certain that large debt stocks lower growth partly by reducing investments. Moreover, the incentive effects associated with debt stocks tend to reduce the benefits to be expected from policy reforms that would strengthen efficiency and growth, such as trade liberalization and fiscal adjustment. The government will be less likely to support current costs if it notices that the future benefit in terms of higher output will grow partly to foreign lenders.

Thereby, some calculations show us that, at a reasonable level of debt. Further borrowing would be expected to have a positive effect on economic growth. Others claim that large accumulated debt stocks may be a barrier to growth. Both these considerations combined together imply that debt is likely to have a neutral effect on growth.

Although the "over hang" theory cannot provide an implicit overview of external debt impact over economic growth, we can analyze the Debt "Laffer Curve" (see fig. 1). As the peak of the Debt "Laffer Curve" shows us the point at which rising debt stocks begin acting as tax on investment or other activities upfront costs in exchange for future investments, the peak also can be the point at which the debt begins to have a negative marginal impact on growth.

The external debt is in a tight relationship with the economic growth. To prove this, we will use several analyses of various debt indicators that take into account the fact that a significant part of the external debt is narrowed at an interest rate below the market rate. It is important because most studies considered debt ratios, such as exports to GDP in nominal terms, meaning that the actual amount they will repay in the future is less than the face value of the debt. To particularly analyze the debt overhang effect with the help of the debt indicators, it is also included the ratio of debt service to exports to control for any displacement effects arising from resources spent on debt service instead of investment or growth strengthening of domestic spending. The debt has indeed an inverted $U$ curve with the growth. When countries open up to foreign markets and start borrowing, the effect on growth is likely to be positive from start. As debt ratio increases, eventually additional debt arises which slows the growth even though the overall debt level continues to provide a positive contribution towards growth. Thus, the peak can be considered as the maximum level of debt. Afterwards the debt goes below zero and creates a negative effect towards growth (see fig. 1).

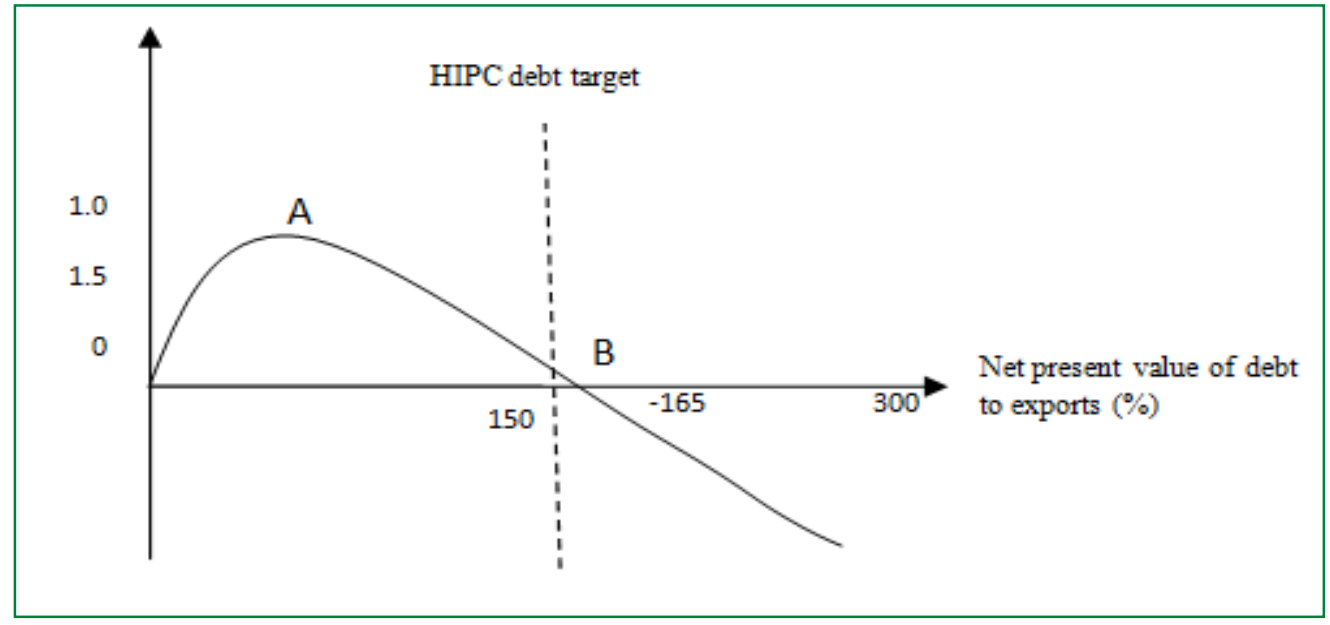

Figure 1. Debt Thresholds

Source: Made by authors in base of [10, PATILLO, C., RICCI, L., 2002]. 
By analyzing the fig. 1, we can notice two critical points. The one where we can identify that at the point $B$, the overall contribution of debt toward growth becomes negative at 160-170 percent of exports and 35-40 percent of GDP. The marginal impact becomes negative at about half of these levels. In particular, it is interesting to denote that countries which benefit from concessional lending are those already which have excessive indebtedness.

The ratio of External debt to GDP is a structural factor influenced by different indicators: the size of the country, the level of economic development and level of economic and financial integration. Countries that are less developed and didn't participate in the globalization or in integration programs have the lowest levels of this indicator. Usually, the critical value of this indicator is at $80 \%$. With the help of this indicator, we can classify the countries in three different categories approved by the World Bank $[2,2000]$ :

$>$ less indebted countries - TED/GDP $\leq 48 \%$;

$>$ moderately indebted countries $-48 \% \leq \mathrm{TED} / \mathrm{GDP} \leq 80 \%$;

$>$ highly indebted countries - TED/GDP $\geq 80 \%$.

For this indicator is very important the marginal rate of debt growth in relation to the rate of growth of Gross Domestic Product. For timely servicing of external debt economic growth rate should be higher than the growth rate of external debt in the current year.

If the economy grows slowly, the government will have to implement some serious adjustments. Whether this really leads to inflation, this depends very much on the monetary policy response. As much as the central bank will maintain the price stability as an objective, any increase of the borrowing will require fiscal adjustments. The relationship between the fiscal and monetary policy is very strongly bounded. This bond describes the relationship explains the long term interest burden and the primary surplus that has to be gathered if the real interest rate is higher than the real economic growth rate. Differently, solvency would always be present. To remove the sovereign default, the interest problem has to be covered by government surpluses gathered in the future. Any increases in the debt ratio, for example an increase in the ratio of the interest rate to the economic growth, will require adjustments, either in the form of higher taxes or reducing the total spending of the country.

The external debt has also an impact on the central banks. If the external debt will grow constantly, the central bank will have to increase the monetary supplies, the monetary base and the level of total reserves also in a relationship with a constant increase of the inflation rate. This process will lead to an increase in revenue from non-interest bearing money creation. Such a shift in policy will be inevitable in the future is enough to lead to an increase in the price level. The real gains from an increase in the inflation rate are rather limited: Revenues generated from non-interest bearing money creation has only a small part from the total revenues of the country. In addition to the idea provided above, an increase in the price level will also decrease the demand for the central bank money.

The price stability can have a significant impact on the economy in the long run. As long as the participants count on price stability, the nominal and real interest rate will also remain low, even if the inflation is quiet high, it will make the external debt manageable for the government. However, high inflation is expected to persist and nominal interest rates will rise sharply because the financial market asks a premium on the risk of asset devaluation through inflation, the high real interest burden can lead to solvency jeopardy. The pressure of the monetary shift to an inflationary policy mounts will lead to an increase in the government's debt ratio.

An inflow of the capital, regardless of where it comes from, will have one or more of the following effects: ${ }^{1}$

$>$ Increasing of the level of foreign investment;

$>$ Increasing of the capacity of obtaining the foreign currency by the respective country, meaning the increasing of the exports or reducing of the imports by means of appropriate investments;

$>$ Incorporation into the investments that do not directly increase the ability to obtain currency (example: in construction);

${ }^{1}$ Băcescu-Cărbunariu Angelica; Condruz-Băcescu Monica, Dependența riscului de ţară față de nivelul datoriei externe, Revista Română de Statistică, Nr.10/2012 
Financing of the speculative activities such as property and stock (including imported stocks);

Offsetting of the private capital outflows due to the political fears or monetary speculation;

Increasing for the government, of the opportunities to avoid the major economic policy transformations such as reducing domestic demand, liberalizing domestic capital markets, encouraging domestic savings or reducing budget deficits;

$>$ Supporting of the consumer spending for medium-sized classes, which are more demanding for imported goods;

$>$ Creating of the sources for military spending;

$>$ Provision of the project or of the other highly profitable businesses that are legally or otherwise intended for government supporters.

To a lesser extent, in most of the countries, we observe a combination of the presented effects. Extreme care should be taken in structuring of the external debt, whether it be its maturity, the currency of the loan or the interest rate. A wrong structure of the external debt is perhaps the most important factor in triggering or accentuation of an economic crisis. Moldova

II. The external debt: a generator of economic crisis or economic solution in the Republic

The Republic of Moldova, as well as other states, call to the foreign loans when domestic savings are insufficient to finance the national consumption and investment. External credits allow the imports to exceed the exports, leading to budget deficit financing and thus delaying important investment projects.

External credits contribute to the acceleration of economic growth, but it is not to be neglected that the country must repay the contracted loans and the related interest.

It is very important for our country to determine the optimal level of indebtedness that the economy can bear. That is why the external debt should be contracted in strict accordance with the needs of the economy, and borrowed loans should consider its reimbursement capacities to avoid the liquidity or solvency crisis.

The external debt of the Republic of Moldova registered an upward trend during the analyzed period, namely an increase from 6 463,89 million USD in 2014 to 7 464,65 million USD in 2018 (see fig. 2).

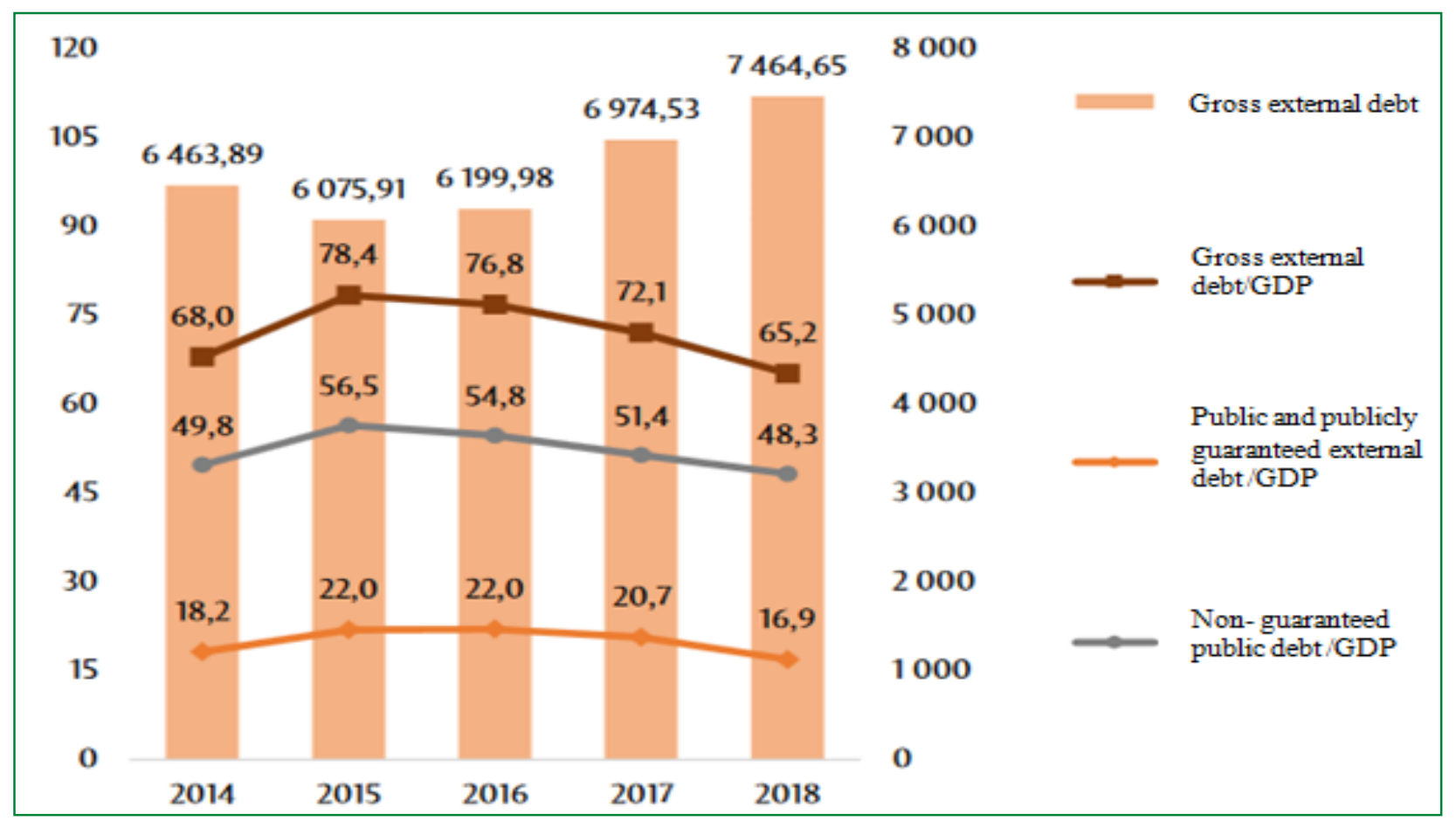

Figure 2. Gross external debt in dynamics, in million USD and \%

Source: In base of data retrieved from www.bnm.org 
The gross external debt of the Republic of Moldova consisted 65,2 \% of the total GDP at the end of 2018, compared with the ratio of $72,1 \%$ in the previous year. If analyzing the evolution of the external debt of the Rep. Moldova, we observe that it started to increase since 2006 followed by a sharp drop in 2008, afterwards rocketed up the next year to 78.82\% from the total GDP [3, IORDACHI, V., CIOBU, S., 2019]. The rate remained practically constant during the years. The highest rate of external debt towards GDP we can notice at the end of 2015, 78,4 \% of the total GDP which is high rate, and as discussed above, we can firmly say that Moldova is a highly indebted country.

The external debt of the Republic of Moldova cannot be considered huge that will lead to an economic crisis. Still, it is above the external debt sustainability level and it can be carefully managed in order to avoid unpleasant economic situations and also budgetary deficits.

To service the external state debt in 2017, the amount of 91,1 million USD (which is the equivalent of 1687,6 million lei) was spent, or with 21,5 million USD $(+31,0 \%)$ more than in 2016 (see table 1). Of the total amount of the expenses destined to service the external state debt, 71,7 million USD (the equivalent of 1329,7 million Lei) constitutes the reimbursement of the principal amounts and 19,4 million USD (the equivalent of 357.9 million lei) - the service of external state debt, which includes the payment of interest and related commissions. Compared to 2016, the servicing of the external state debt registered an increase both at the repayment of the principal $(+16,4$ million USD/ $+29,7 \%)$ and at the payment of the related interests $(+5,1$ million USD $/+35,9 \%)[5,2018]$.

Table 1

Evolution of expenditures for servicing the external state debt in 2015-2017, mil. Lei

\begin{tabular}{|l|c|c|c|c|}
\hline \multicolumn{1}{|c|}{ Year } & $\mathbf{2 0 1 5}$ & $\mathbf{2 0 1 6}$ & $\mathbf{2 0 1 7}$ & $\begin{array}{c}\text { Deviations, 2017 } \\
\text { compared to 2016 }\end{array}$ \\
\hline \multicolumn{1}{|c|}{1} & 2 & 3 & 4 & $5=4-3$ \\
\hline $\begin{array}{l}\text { Servicing the external state debt, } \\
\text { out of which: }\end{array}$ & $\mathbf{9 7 4 , 0}$ & $\mathbf{1 3 9 2 , 0}$ & $\mathbf{1 6 8 7 , 6}$ & $\mathbf{2 9 5 , 6}$ \\
\hline Repayment of principal amount & 724,3 & 1107,3 & 1329,7 & 222,4 \\
\hline $\begin{array}{l}\text { Payment of interest and } \\
\text { commissions }\end{array}$ & 249,7 & 284,6 & 357,9 & $\mathbf{7 3 , 3}$ \\
\hline State debt service growth rate,\% & $+76,3$ & $+67,5$ & $+10,4$ & $\mathrm{x}$ \\
\hline GDP growth rate, \% & $+9,4$ & $+10,5$ & $+11,1$ & $\mathrm{x}$ \\
\hline $\begin{array}{l}\text { State budget expenditures growth } \\
\text { rate, \% }\end{array}$ & $+2,6$ & $+7,3$ & $+9,9$ & $\mathrm{x}$ \\
\hline
\end{tabular}

Source: Decision nr. 25 from 28.05.2018 on the Report on management performance audit of the public sector debt in 2017 [online]. Available on:

http://lex.justice.md/index.php?action=view\&view=doc\&lang=1\&id=376291.

The summary of the expenditures intended for servicing the external state debt in the years 2015-2017 is presented in table 2 .

Table 2

Service of the external state debt in 2015-2017

\begin{tabular}{|c|c|c|c|c|c|c|}
\hline \multirow{2}{*}{ Year } & \multicolumn{2}{|c|}{ Total payed } & \multicolumn{2}{c|}{$\begin{array}{c}\text { Reimbursement of the } \\
\text { principal }\end{array}$} & \multicolumn{2}{c|}{$\begin{array}{c}\text { Payment of interest and } \\
\text { commissions }\end{array}$} \\
\cline { 2 - 7 } & mil. USD & mil. Lei & mil. USD & mil. Lei & mil. USD & mil. Lei \\
\hline 2017 & 91,1 & 1687,6 & 71,7 & 1329,7 & 19,4 & 357,9 \\
\hline 2016 & 69,6 & 1392,0 & 55,3 & 1107,3 & 14,3 & 284,6 \\
\hline 2015 & 51,8 & 974,0 & 38,5 & 724,3 & 13,3 & 249,7 \\
\hline
\end{tabular}

Source: Decision nr. 25 from 28.05.2018 on the Report on management performance audit of the public sector debt in 2017 [online]. Available on:

http://lex.justice.md/index.php?action=view\&view=doc\&lang=1\&id=376291.

The increase of the expenses for servicing the external state debt is caused by the increase of the payments destined for the repayment of the principal amount, as well as by the beginning of the 
repayment of the loan (tranche 3) granted by the IMF to support the budget in 2010 (76,2 million Lei), of the loan (tranche 1) granted by Romania in 2015 (158,0 million lei) and the loan (tranche 3 ) granted by the EIB for the implementation of the project "European Roads" (11,2 million lei).

When developing countries pay their interest rates and maturity rates on contracted loans, they often sacrifice the development of the education or health systems, economic growth and raising the standard of living of citizens. It is essential for the borrowing country that contracted and used external loans contribute to the development and modernization of the economy and investment in infrastructure and not to increase of consumption.

The financial resources should flow from the developed countries to the developing ones, but it is more and more obvious that this flow has been reversed due to the increasing amounts due to the repayments of credits contracted in the previous periods. This makes it difficult for developing countries to show upward growth trends and reduce the poverty.

The foreign loans allow the Republic of Moldova's economy to invest and consume beyond its domestic capacity, and allow the capital formation to be funded from both internal resources and resource-attracting by countries with the surplus of the capital. The external lending can lead to a faster economic growth, allowing more substantial investment to be funded, and mobilizing the resources available to the country, while giving it a more reserved, prudent and even more efficient use. They do not contribute to boosting of the economic growth as they are used to fund nonproductive activities or to counterbalance of the excessive capital exports. In this case, these loans could even exacerbate the pressures on budgetary and balance-of-payments operations.

The idea that should govern the realistic appreciation of the external debt of the Republic of Moldova is, as with other economic processes, the reporting of the external debt costs to the advantages resulting from the foreign capital use or, in other words, the reporting of difficulties arising from the external debt service to the consolidation of the market economy.

A country's external indebtedness is a natural transaction that confers on domestic or foreign economic agents the realization of mutually beneficial inter-temporal arbitrages that a closed economy cannot offer. Although they are natural and add to the efficiency of the economic system, however, the capital flows can lead to a crisis of indebtedness, considering that they create problems on the one hand and solve them on another hand.

We believe that not the existence of the external debt is a problem for the economy of the Republic of Moldova, but its size, currency structure and the interest rates; if the contracted debts record very high levels, their costs can become extremely high, both economically and socially, culminating in the outbreak of a foreign debt crisis.

Moldova's risk of debt distress remains low, in the line of year 2017. All external indicators for public debt remain well below the debt threshold under the baseline, standard bound tests, and alternative scenarios. Although, as Moldova is most sensible to exchange rates depreciation, and as there was a sudden increase in other debt creating flows, Moldova's general public debt dynamics are projected to remain on a normal path under the baseline scenarios and also under the threshold. Nonetheless, Moldova needs careful and firm fiscal policy, and has to implement and improve its structural reforms to ensure the debt sustainability. Because of that Moldova is sensible to exogenous developments, and banking crisis, debt sustainability is strictly based on sound macroeconomic management and continuing progress on institutional and structural issues that would help to open the economy's growth ability and reduce its vulnerability to shocks. In addition, the limited development of domestic debt market poses financial risk, considering the country's necessity to development and significant dependence on foreign aid in the form of grants and concessional loans. The country has to implement several policies and put some effort to lengthen the average maturity of the domestic debt and sink the secondary market.

In the medium term the tendency of covering the state budget balance (deficit) predominantly from external sources prevails. This development reveals the considerable dependence of the Republic of Moldova on external creditors and, implicitly, the financial and structural conditions for accessing foreign funds.

In the period 2018-2020 it is estimated that the Government will benefit from foreign state borrowing, which will be directed, on average, to $22,9 \%$ for the budget support, and for the 
financing of the investment projects - of about $77,1 \%$. At the same time, foreign state loans will be granted almost entirely by multilateral institutions during this period. The medium-term structure of external financing by category of instruments is presented in table 3 .

Table 3

External financing during the years 2018-2020, according to the baseline scenario

\begin{tabular}{|l|c|c|c|c|}
\hline \multicolumn{1}{|c|}{ Indicators } & U/M & $\mathbf{2 0 1 8}$ & $\mathbf{2 0 1 9}$ & $\mathbf{2 0 2 0}$ \\
\hline External debt financing including: & \% from GDP & $4.8 \%$ & $4.6 \%$ & $3.3 \%$ \\
\hline $\begin{array}{l}\text { Loans from multilateral creditors at } \\
\text { concessional terms }\end{array}$ & \% from total & $1.8 \%$ & $1.5 \%$ & $1.4 \%$ \\
\hline $\begin{array}{l}\text { Loans from multilateral creditors at } \\
\text { semi concessional terms }\end{array}$ & \% from total & $38.3 \%$ & $38.4 \%$ & $32.8 \%$ \\
\hline $\begin{array}{l}\text { Loans from multilateral lenders with } \\
\text { variable interest rate }\end{array}$ & \% from total & $59.9 \%$ & $60.1 \%$ & $65.8 \%$ \\
\hline $\begin{array}{l}\text { Loans from bilateral creditors with } \\
\text { fixed interest rate }\end{array}$ & \% from total & $0.1 \%$ & $0.0 \%$ & $0.0 \%$ \\
\hline
\end{tabular}

Source: Elaborated by author based on Interactive Database of Government of Moldova [online]. Available on: http://lex.justice.md/UserFiles/File/2018/mo7-17md/program_1148.docx.

The structure of creditors of forecasted sources of external financing reveals the most important creditors for the period 2018-2020, as follows:

$>$ European Investment Bank - 30,6\%;

$>$ World Bank Group - 28,9\%;

$>$ European Bank for Reconstruction and Development - 23,3\%;

$>$ European Commission - 5,6\%;

$>$ Council of Europe Development Bank - 5,6\%;

$>$ International Monetary Fund - 4,3\%;

$>$ International Fund for Agricultural Development - 1,6\%;

Government of Poland - 0,02\%.

From the previous years, taking into account the constraints imposed by the local financial market, the Ministry of Finance intends to initiate a transition process, which will start with the implementation of the S1 with medium-term orientation towards: the possibility of extending the financing from the creditors bilateral agreements in order to reduce the impact of reducing external financing on concessional and semi-concessional terms; developing new instruments to be issued on the domestic market, focusing on expanding their maturity and analyzing the possibility of issuance of state securities on international markets, thus increasing the attractiveness of the SS local market but taking into account the implications of the exchange rate in this respect.

At the same time, the Ministry of Finance will continue to maintain a flexible approach to the process of financing the state budget deficit (deficit) on the local market, in order to ensure the predictability and transparency of the state securities offer, in order to be able to react promptly to possible changes in the market trends and investor behavior $[8,2017]$.

There are other risks which can significantly influence the economy of the country and also affect negatively the external debt of the country. Here we can list some potential risks that can arise in the long run in the development process of the country:

$>$ uncertainty about disbursements from official creditors, taking into account the country's dependence on external development partners;

$>$ failure to implement the originally planned deficit target in the budget;

$>$ global uncertainty about the influence of the monetary policy conduct of the main central banks of the world (the ECB and the Fed) and the consequences of the referendum in the UK;

$>$ increase of the inflation rate and tightening of the monetary policy of the National Bank of Moldova;

$>$ depreciation of the official currency exchange rate of the national currency relative to the main currencies in which the external debt is denominated; 
$>$ political instability and unpredictability of political decisions;

$>$ diminishing national and international credibility for SS investors;

$>$ operational risk, and other risks that can arise during the years.

All the above mentioned risks can have a negative influence on the national economy of the Republic of Moldova. These risks can lead to major problems in the country, for example the failure to implement the deficit objectives planned from the start can lead to additional unplanned costs and also will lead to external debt growth. The country will have to find other sources in order to cover the deficit gap. In order to avoid such situations or to deal correctly with this risk, the country has to improve the fiscal policy and to analyze it in correlation with the external debt of the country. Inefficient fiscal policies can make it difficult to achieve the planned objectives for the upcoming year and also will cause additional expenses in order to cover the debts. The government has to make a strict relationship between the external debt and the correct administration of the government's liquid assets.

In order to deal with the problem of official exchange rate depreciation in relation with the main currencies in which the external debt is denominated, the government has to increase the share of net financing in national currency, which would facilitate the reduction of foreign exchange exposure, while taking into account the absorption capacity of the domestic market and, in general, the demand for debt instruments, expressed in MDL. The government has also to apply provisions to the estimate of the government debt balance and its service costs in the event of significant fluctuations in the official currency of the domestic currency.

Republic of Moldova has to make big changes in the external debt management in order to at least maintain the external debt and not to make it grow higher and to be ready to deal with potential risks that can arise during the time. If the diminishing national and international credibility for SS investors will arise, it will cause huge troubles for the country. First of all, it will lead to a decrease in the SS because the investors will lose their desire to invest. In such a way, the country will not be able to finance its project and also to cover its deficit gap from the existent sources of funding from the local market. It will have a huge impact on the economic growth of the country and it will also lead to an increase in the public debt of the country.

CONCLUSIONS. As the external debt of the Republic of Moldova cannot be considered huge that will lead to an economic crisis. Still, it is above the external debt sustainability level and it should be carefully managed in order to avoid unpleasant economic situations and budgetary deficits. The country has to analyze carefully its investment portfolio for the planned projects and also to compact the projects by giving priority to the most important projects for the national economy. It will help the government to repay the existing debts from their revenues. Also the government has to improve their SS securities market, the primary and the secondary market in order to diversify the potential sources of finance. The government can transform the local financial market into a stable source of funding for budgeting and also it can diversify the domestic debt instruments and increasing their attractiveness. It is not necessary only to issue the securities only on the local market, but to have positive results, the government has to analyze the opportunity and take the necessary actions to enter the international financial markets by issuing bonds in foreign currency. The government has to supervise regularly the sustainability indicators of the state debt so that their dynamics will be within acceptable limits in the medium term and also to analyze the financial conditions of the newly borrowed external loans, the most optimal variant in terms of maturity of the loan and interest rate at the negotiation stage, for each individual loan.

\section{REFERENCES}

1. BĂCESCU-CĂRBUNARIU, A., CONDRUZ-BĂCESCU, M. Dependenţa riscului de ţară faţă de nivelul datoriei externe. In: Revista Română de Statistică. 2012, nr. 10, pp. 57-62. [Accesat 30.09.2019]. Disponibil: http://www.revistadestatistica.ro/wpcontent/uploads/2014/02/RRS_10_2012_A4_ro.pdf

2. Guidelines for Public Debt Management. International Monetary Fund, World Bank. 2000, march 21. [Accesat 30.09.2019]. Disponibil: https://www.imf.org/external/np/mae/pdebt/2000/eng/guide.pdf 
3. IORDACHI, V., CIOBU, S. Sovereign external debt management in the Republic of Moldova challenges and sollutions. In: The journal Contemporary Economy. 2019, vol. 4, issue 2, pp. 92102. ISSN 2537-4222.

4. KRUGMAN, P. Financing vs. forgiving a debt overhang. In: Journal of development Economics. 1988, vol. 29 (3), pp. 253-268. ISSN 0304-3878.

5. Hotătîre cu privire la Raportul auditului performanței managementului datoriei sectorului public în anul 2017: nr. 25 din 28.05.2018. In: Monitorul Oficial al Republicii Moldova. 2018, nr. 246-254, art. 25. [Accesat 13.10.2019]. Disponibil:

http://lex.justice.md/index.php?action=view\&view=doc\&lang=1\&id=376291

6. Hotarare cu privire la unele măsuri de executare a Legii nr. 419-XVI din 22 decembrie $2006 \mathrm{cu}$ privire la datoria sectorului public, garanțiile de stat și recreditarea de stat: nr. 1136 din 18.10.2007. In: Monitorul Oficial al Republicii Moldova. 2007, nr. 175-177, art. 1216. [Accesat 15.05.2019]. Disponibil: http://lex.justice.md/md/325680/

7. Lege cu privire la datoria publică, garanțiile de stat și recreditarea de stat: nr. 419 din 22.12.2006. In: Monitorul Oficial al Republicii Moldova. 2007, nr. 32-35, art. 114. [Accesat 15.05.2019]. Disponibil: http://lex.justice.md/viewdoc.php?action=view\&view=doc\&id=333420\&lang=1

8. Managementul datoriei de stat pe termen mediu (2018-2020): program. 2017. [Accesat 15.05.2019]. Disponibil: http://lex.justice.md/UserFiles/File/2018/mo7$17 \mathrm{md} /$ program_1148.docx

9. Notă cu privire la prognoza principalilor indicatori macroeconomici pentru anii 2020-2022. [Accesat 15.05.2019]. Disponibil: https://mei.gov.md/sites/default/files/document/attachments/nota_prognoza_macroeconomi ca.pdf

10. PATILLO, C., RICCI, L. External Debt and Growth. In: Finance and Development. 2002, vol. 39, no. 2. [Accesat 15.05.2019]. Disponibil:

http://www.imf.org/external/pubs/ft/fandd/2002/06/pattillo.htm

\section{ARTICLE HISTORY}

Received 04 November 2019

Accepted 02 December 2019 